\title{
PERANCANGAN DAN KARAKTERISASI ANTENA MONOPOLE SEBAGAI PEMANCAR DAN PENERIMA GELOMBANG WIFI FREKUENSI 2,4 GHZ
}

\author{
DESIGN AND CHARACTERIZATION OF MONOPOLE ANTENNA AS TRANSMITTER \\ AND RECEIVER WIFI WAVE AT 2.4 GHZ FREQUENCY
}

\author{
Kezia Noviani Anou
}

${ }^{1}$ Jurusan Fisika, FMIPA, Universitas Cenderawasih, Jayapura, 99333, Indonesia

*Email: keziaanou@gmail.com

\begin{abstract}
ABSTRAK
Desain dan karakterisasi antena monopole sebagai pemancar dan penerima gelombang wifi dengan frekuensi 2,4 GHz pada pipa besi telah dilakukan. Metode pengambilan data pada penelitian ini dilakukan secara langsung. Jenis antena yang didisain adalah 2 antena monopole $1 / 4 \lambda$ yang dibuat dari kawat tembaga dengan ketebalan wire $2.25 \mathrm{~mm}$ dan keliling wire $0.004 \mathrm{~mm}$. Antena monopole $1 / 4 \lambda$ ini memiliki panjang gelombang sebesar $12,5 \mathrm{~cm}$ dan panjang wire $3,125 \mathrm{~cm}$. Karakterisasi parameter antena monopole menggunakan Network Analyzer. Pengujian antena monopole menunjukkan nilai impedansinya adalah $\mathrm{Z}=41,4+\mathrm{j} 10,8 \Omega$. Nilai return loss sebesar $-10.35 \mathrm{~dB}$ pada frekuensi $348 \mathrm{MHz}$ dan lebar bandwidth yang dihasilkan sebesar 3,48 GHz-1,58 GHz =1,9 $\mathrm{GHz}$ dengan frekuensi pusat di 2,4 GHz. Nilai VSWR adalah sebesar 1,358 dB. Nilai $V S W R$ umumnya memiliki nilai $1 \leq V S W R \leq 2$ dimana dalam keadaan ideal, $V S W R$ bernilai 1. Artinya, impedansi saluran transmisi (port) dengan antena memiliki nilai yang sama sehingga sinyal dapat sepenuhnya ditransmisikan melalui saluran (pipa besi) menuju antena penerima.
\end{abstract}

Kata kunci: Antena Monopole, Transmisi, Network Analyzer, Impedansi, Return Loss, Bandwidth, VSWR

\begin{abstract}
The design and characterization of a monopole antenna as a wifi transmitter and receiver with a frequency of $2.4 \mathrm{GHz}$ on an iron pipe has been carried out. The data collection method in this research is done directly. The type of antenna designed is 2 of 1/4 $\lambda$ monopole antennas made of copper wire with a wire thickness of $2.25 \mathrm{~mm}$ and a wire

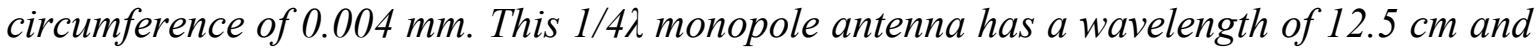
a wire length of $3.125 \mathrm{~cm}$. Monopole antenna parameter characterization using Network Analyzer. Monopole antenna testing shows the impedance value is $Z=41.4+j 10.8 \Omega$. The return loss value is $-10.35 \mathrm{~dB}$ at a frequency of $348 \mathrm{MHz}$ and the resulting bandwidth is $3.48 \mathrm{GHz}-1.58 \mathrm{GHz}=1.9 \mathrm{GHz}$ with a center frequency of $2.4 \mathrm{GHz}$. The VSWR value is $1.358 \mathrm{~dB}$. VSWR values generally have a value of $1 \leq V S W R \leq 2$ where in ideal circumstances, VSWR is 1. That means the impedance of the transmission line (port) and the antenna has the same value so that the signal can be fully transmitted through the line (iron pipe) to the receiver antenna.
\end{abstract}

Keywords: Monopole Antenna, Transmission, Network Analyzer, Impedance, Return Loss, Bandwidth, VSWR 


\section{PENDAHULUAN}

Komunikasi tanpa kabel/nirkabel(wi reles) telah mejadi kebutuhan dasar atau gaya hidup baru masyarakat informasi. $L A N$ nirkabel yang lebih dikenal dengan jaringan $W i-F i$ menjadi teknologi alternatif dan relatif lebih mudah untuk diimplementasikan di lingkungan kerja (SOHO/ Small Office Home Office), seperti di perkantoran, laboratorium computer, ataupun dilingkungan masyarakat dan sebagainya. Instalasi perangkat jaringan $W i-F i$ lebih fleksibel karena tidak membutuhkan penghubung kabel antarkomputer yang hanya membutuhkan ruang atau space dengan syarat jarak jangkauan dibatasi kekuatan pancaran sinyal radio dari masing-masing komputer (Priyambodo, 2005).

IEEE mendefinisikan sebuah antena sebagai bagian dari sistem pemancaran dan penerimaan yang didesain untuk meradiasikan atau untuk menerima gelombang elektromagnetik. Sebuah garis transmisi memerlukan struktur pemandu (pandu gelombang), sedangkan sebuah antena tidak memerlukan struktur pemandu. Antena dapat dipandang juga sebagai transducer yang mengubah sebuah pandu gelombang pada garis transmisi kepada ruang bebas gelombang elektromagnetik untuk kasus pemancaran dan sebaliknya untuk kasus penerimaan gelombang.

Antena monopole adalah antena yang dikenal sebagai antena yang dapat mengimplementasikan VSWR rendah dalam lebar pita. Dalam disainnya, dimana panjang dari sebuah monopole adalah $1 / 4 \lambda$ dari frekuensi minimum atau lebih (Kobayasi, Takehiko).

Antena monopole juga merupakan antena yang memiliki panjang setengah dari panjang antena dipol yang berada pada bidang yang digroundkan maka untuk setiap parameter antena monopole memiliki nilai setengah dari nilai antena dipol_(Orfanidis, 2008).

Dalam penelitian ini dilakukan karakterisasi dua buah antena monopole $1 / 4 \lambda$ sebagai pemancar dan penerima sinyal wifi frekuensi $2,4 \mathrm{GHz}$ pada pipa besi.

\section{METODE PENELITIAN}

\section{Perancangan Antena Monopole $1 / 4 \lambda$}

Pada penelitian kali ini diawali dengan perancangan antena monopole yang dirancang dengan panjang $1 / 4 \lambda$. Penelitian ini menggunakan dua antena monopole kemudian merangkainya dengan konektor yang terhubung pada dua access point dengan frekuensi 2.4 $\mathrm{GHz}$, masing-masing berfungsi sebagai server dan receiver. Untuk mencari panjang antena terbaik digunakan rumus: 


$$
\lambda=\frac{c}{\text { fkerja }}=\frac{3 \times 10^{8}}{2.4 \times 10^{9}}=0.125 \mathrm{~m}
$$

karena menggunakkan antena monopole $1 / 4 \lambda$ maka:

$\frac{1}{4} \lambda=\frac{1}{4}(0.125)=0.03125 \mathrm{~m}=$

\section{$3.125 \mathrm{~cm}$}

Jadi panjang antena yang akan digunakan oleh 2 antena monopole adalah $3.125 \mathrm{~cm}$.

2. Karakterisasi antena monopole $1 / 4 \lambda$

\section{a. Network Analyzer}

Network Analyzer merupakan alat ukur yang digunakan untuk mengukur parameter medan jauh dan medan dekat pada antena. Parameter medan dekat sendiri terdiri dari Impedansi, Return Loss, Bandwidth antena dan VSWR. Sedangkan pada medan jauh terdiri dari Gain, Direktivitas, Pola radiasi dan Polarisasi antena.

\section{b. Impedansi}

Untuk pemindahan energi yang efisien, impedansi radio, antena, dan kabel pengiriman yang menyambungkan harus sama. Transceivers dan kabel penghubung biasanya didesain

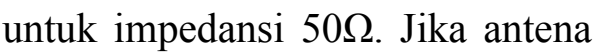
mempunyai impedansi berbeda

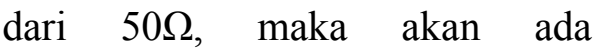
ketidakcocokkan dan sebuah rangkaian pencocok impedansi akan diperlukan. Ketika impedansi tidak cocok maka efisiensi pengiriman menurun.

\section{c. Return Loss}

Return loss adalah cara lain mengungkapkan ketidakcocokan. Return loss adalah rasio logaritma yang diukur dalam $\mathrm{dB}$ yang membandingkan daya yang dipantulkan oleh antena dengan daya yang masukkan kedalam antena dari jalur pengiriman. Hubungan antara SWR dan Return Loss (RL) adalah sebagai berikut:

$$
R L=-20 \log _{10}|\Gamma|(3)
$$

Pada saat sebagian energi dipantulkan kembali ke dalam sistem, maka akan menghasilkan kinerja antena yang tidak maksimal (Purbo, 2007).

\section{d. Bandwidth}

Bandwidh atau lebar pita frekuensi dari suatu antena adalah rentang daerah frekuensi kerja dimana antena dapat bekerja efektif dan lebih baik. Perhitungan bandwidth antena dibatasi oleh VSWR $\leq 1.5$ atau $R L \leq-15 \mathrm{~dB}$. 
e. Voltage Standing Wave Ratio (VSWR)

Voltage standing wave Ratio (VSWR) adalah besaran yang menyatakan rasio perbandingan tegangan maksimum dan tegangan minimum di sepanjang transmission line (Muhtadi, 2009). Penggunaan VSWR berhubungan dengan pengukuran koefisien refleksi dari antena tersebut $(\Gamma)$.

$$
\Gamma=\frac{V_{\text {pantul }}}{V_{\text {input }}}
$$

Nilai VSWR merupakan represe ntasi standing wave. Peristiwa Standing wave terjadi jika terdapat dua gelombang yang merambat pada arah berlawanan dalam media yang sama dimana frekuensi antara gelombang datang dengan gelombang yang dipantulkan adalah sama.

$$
V S W R=\frac{1+|\Gamma|}{1-|\Gamma|}
$$

\section{HASIL DAN PEMBAHASAN}

\section{Hasil Perancangan Antena}

Pada penelitian ini telah difabrikasi 2 antena monopole $1 / 4 \lambda$ dibuat dari kawat tembaga dengan ketebalan wire 2,25 $\mathrm{mm}$ dan keliling wire $0.004 \mathrm{~mm}$. Antena monopole $1 / 4 \lambda$ ini memiliki panjang gelombang sebesar $12,5 \mathrm{~cm}$ dan panjang wire $3,125 \mathrm{~cm}$. Dapat dilihat hasil fabrikasi antena monopole seperti pada gambar 1 .

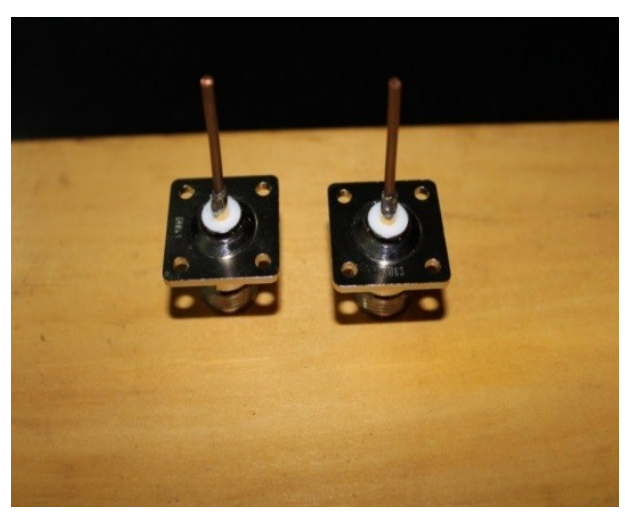

Gambar 1. Antena monopole 1/4 $\lambda$

2. Hasil Karakterisasi Antena Monopole $1 / 4 \lambda$

\section{a. Impedansi}

Telah dilakukan pengukuran menggunakan Network Analyzer untuk mengkarakterisasi nilai impedansi, VSWR, return loss dan bandwidth. Pada gambar 2 diperlihatkan nilai impedansi yaitu $Z=41,4+\mathrm{j} 10,8 \Omega$. Nilai real 41,4 $\Omega$ menyatakan nilai reaktansi resistif dan nilai imajiner $+\mathrm{j}$ $10,8 \Omega$ menyatakan nilai reaktansi induktif. 


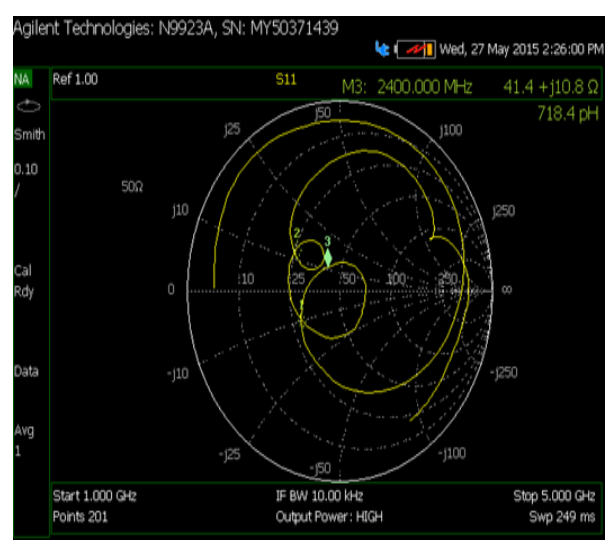

Gambar 2. Impedansi antena

monopole

\section{b. Return Loss dan Bandwidth}

Grafik nilai return loss diperlihatkan pada gambar 3. Dari grafik diperoleh nilai return loss sebesar -10.35 dB pada frekuensi $348 \mathrm{MHz}$. Dengan menggunakan persamaan Bandwidth narrowband :

Bandwidth $_{n b}=\frac{f_{2-f_{1}}}{f_{c}} \times 100 \%$

diperoleh lebar bandwidth yang dihasilkan sebesar 3,48 GHz-1,58 $\mathrm{GHz}=1,9 \mathrm{GHz}$, dengan frekuensi pusat di 2,4 GHz.

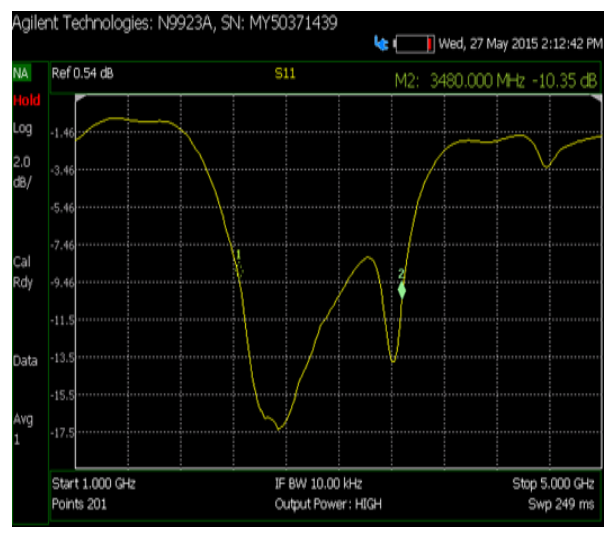

Gambar 3. Grafik return loss

\section{c. VSWR}

Grafik nilai VSWR yang dihasilkan diperlihatkan pada Gambar 4. Diperoleh nilai $V S W R$ adalah sebesar $1.358 \mathrm{~dB}$ yang diharapkan dapat bekerja pada frekuensi $2.4 \mathrm{GHz}$. Nilai VSWR hanya ditinjau pada titik frekuensi tersebut. Nilai VSWR umumnya memiliki nilai $1 \leq V S W R \leq$ 2 dimana dalam keadaan ideal, VSWR bernilai 1. Artinya, impedansi saluran transmisi (port) dengan antena memiliki nilai yang sama sehingga sinyal dapat sepenuhnya ditransmisikan melalui saluran menuju antena. Sehingga antena monopole hasil fabrikasi masih memenuhi rentang nilai VSWR yang diperbolehkan. 


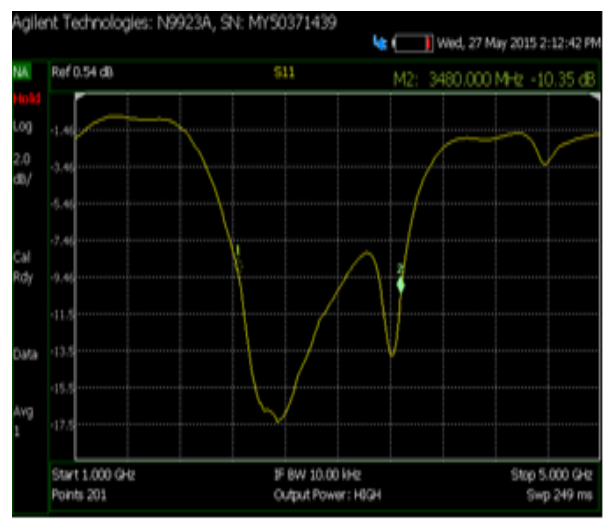

Gambar 4. Grafik hubungan antara frekuensi dan nilai $V S W R$

\section{KESIMPULAN}

Dari penelitian yang dilakukan, desain antena monopole $1 / 4 \lambda$ sebagai pemancar dan penerima gelombang wifi frekuensi 2,4 $\mathrm{GHz}$ dibuat dari kawat tembaga dengan ketebalan wire 2,25 mm dan keliling wire $0.004 \mathrm{~mm}$. Antena monopole $1 / 4 \lambda$ ini memiliki panjang gelombang sebesar $12,5 \mathrm{~cm}$ dan panjang wire $3,125 \mathrm{~cm}$. Sedang hasil karakterisasinya menghasilkan nilai impedansi yaitu $Z=41,4+\mathrm{j} 10,8 \Omega$. Dari grafik diperoleh nilai return loss sebesar $10.35 \mathrm{~dB}$ pada frekuensi $348 \mathrm{MHz}$ dan lebar bandwidth sebesar 3,48 GHz-1,58 $\mathrm{GHz}=1,9 \mathrm{GHz}$, dengan frekuensi pusat di 2,4 GHz. Grafik nilai VSWR yang dihasilkan diperlihatkan pada Gambar 4, diperoleh nilai VSWR adalah sebesar $1.358 \mathrm{~dB}$. Dari keseluruhan parameter nilai yang didapat maka semuanya memiliki kecocokan sehingga antena monopole hasil fabrikasi dinyatakan dapat mengantarkan seluruh sinyal yang ditransmisikan dengan baik melalui pipa kepada antena monopole penerima yang telah diujikan cobakan pada penelitian berikutnya.

\section{DAFTAR PUSTAKA}

Kobayasi,Takehiko.”A planar UWB Monopole Antenna Formed on a printed Circuit Board". Tokyo Denki University

Muhtadi, D. (2009), Desain Fabrikasi Dan Karakterisasi Antena Wideband Mikrostrip Slot Bowtie dengan CPW Untuk Komunikasi Wireless, Magister Tesis Program Pasca Sarjana Fisika, Fakultas Matematika dan Ilmu Pengetahuan Alam, Institut Teknologi Sepuluh Nopember, Surabaya

Orfanidis. J.S ophocles. 2008. Elctromagnetic Waves And Antennas. Ruger University

Priyambodo, T.K. 2005. Jaringan Wi-Fi. Yogyakarta. C.V Andi Offset 
Purbo, W.Onno .2007. Jaringan Wireless

Di Dunia Berkembang.

Yogyakarta:CV. Andi Offset

https://fit.labs.telkomuniversity.ac.id/net

work-analyzer-dan-

fungsinya/(Diakases pada 4 Januari

2019) 